Bull. Mater. Sci., Vol. 36, No. 3, June 2013, pp. 491-494. (c) Indian Academy of Sciences.

\title{
Synthesis, characterization and oxide ionic conductivity of $\beta$-type solid solution in bismuth oxide doped with ytterbium oxide binary system
}

\author{
ESRA ÖZTÜRK* ${ }^{*}$ NILGUN OZPOZAN KALAYCIOGLU ${ }^{\dagger}$, SERKAN DAYAN ${ }^{\dagger}$ \\ and HANDAN OZLU ${ }^{\dagger}$ \\ Department of Material Science and Engineering, Faculty of Engineering, Karamanoğlu Mehmetbey University, \\ Karaman 70200, Turkey \\ ${ }^{\dagger}$ Department of Chemistry, Faculty of Science, Erciyes University, Kayseri 38039, Turkey
}

MS received 14 October 2011; revised 11 May 2012

\begin{abstract}
In this study, after doping $\mathrm{Yb}_{2} \mathrm{O}_{3}$ substance to $\alpha-\mathrm{Bi}_{2} \mathrm{O}_{3}$ substance in the range of $1 \% \leq n \leq 8 \%$ in a series of different mole ratios, heat treatment was performed by applying a cascade temperature rise in the range of 700-790 ${ }^{\circ} \mathrm{C}$ for 48 and $120 \mathrm{~h}$ and new phases were obtained in the $\left(\mathrm{Bi}_{2} \mathrm{O}_{3}\right)_{1-x}\left(\mathrm{Yb}_{2} \mathrm{O}_{3}\right)_{x}$ system. After $48 \mathrm{~h}$ of heat treatment at $750{ }^{\circ} \mathrm{C}$ and $120 \mathrm{~h}$ of heat treatment at $790{ }^{\circ} \mathrm{C}$, mixtures containing $1-8 \%$ mole $\mathrm{Yb}_{2} \mathrm{O}_{3}$ formed a tetragonal phase. With the help of XRD, crystal systems and lattice parameters of the solid solutions were obtained and their characterization was carried out. Thermal measurements were made by using a simultaneous DTA/TG system. The total conductivity $\left(\sigma_{T}\right)$ in the $\beta-\mathrm{Bi}_{2} \mathrm{O}_{3}$ doped with $\mathrm{Yb}_{2} \mathrm{O}_{3}$ system was measured using four-probe d.c. method.
\end{abstract}

Keywords. Bismuth oxide; ytterbium oxide; oxygen ionic conductivity; X-ray techniques; thermal analysis.

\section{Introduction}

Until now, researchers have reported six polymorphs of bismuth trioxide $\left(\mathrm{Bi}_{2} \mathrm{O}_{3}\right)$. These are monoclinic $\left(\alpha-\mathrm{Bi}_{2} \mathrm{O}_{3}\right)$, body-centred cubic $(b c c)\left(\gamma-\mathrm{Bi}_{2} \mathrm{O}_{3}\right)$, face-centred cubic (fcc) $\left(\delta-\mathrm{Bi}_{2} \mathrm{O}_{3}\right)$, tetragonal $\left(\beta-\mathrm{Bi}_{2} \mathrm{O}_{3}\right)$, triclinic $\left(\omega-\mathrm{Bi}_{2} \mathrm{O}_{3}\right)$ and orthorhombic $\left(\varepsilon-\mathrm{Bi}_{2} \mathrm{O}_{3}\right)$ phases (Takahashi et al 1977; Harwig 1978; Sammes et al 1999; Leontie et al 2001; Chehab et al 2003; Crumpton et al 2003; Ozpozan and Çırçır 2012). The $\alpha$-phase is stable at room temperature while other five forms are unstable crystal modifications that are formed at high temperatures. If pure $\alpha-\mathrm{Bi}_{2} \mathrm{O}_{3}$ whose melting temperature is $824{ }^{\circ} \mathrm{C}$ is heated until around $729{ }^{\circ} \mathrm{C}$, it transforms into the $\delta-\mathrm{Bi}_{2} \mathrm{O}_{3}$ phase, which is stable at high temperature and this phase is stable up to melting point. When it is cooled again, it transforms into the $\beta-\mathrm{Bi}_{2} \mathrm{O}_{3}$ phase at $\sim 650{ }^{\circ} \mathrm{C}$ and the $\gamma-\mathrm{Bi}_{2} \mathrm{O}_{3}$ phase at $\sim 639{ }^{\circ} \mathrm{C}$. If the $\beta$ - and $\gamma$-phases are cooled to lower temperatures, they transform into the $\alpha-\mathrm{Bi}_{2} \mathrm{O}_{3}$ phase again at around $\sim 500{ }^{\circ} \mathrm{C}$. Orthorhombic $\left(\varepsilon-\mathrm{Bi}_{2} \mathrm{O}_{3}\right)$ and triclinic $\left(\omega-\mathrm{Bi}_{2} \mathrm{O}_{3}\right)$ phases, of which there is scarce information, can be obtained with notable special synthesis reactions and hydrothermal heat treatment processes at 240 and $800{ }^{\circ} \mathrm{C}$, respectively (Harwig 1978; Kalaycioglu and Çırçır 2011).

Bismuth oxide $\left(\mathrm{Bi}_{2} \mathrm{O}_{3}\right)$ has been widely used in gas sensors, solid oxide fuel cells, optical coatings, etc, owing to their excellent properties, such as high refractive index, high

\footnotetext{
*Author for correspondence (esracircir@gmail.com)
}

ion conductivity and ascendant photoluminescence properties (Shuk et al 1996; Cabot et al 2004; Leontie et al 2005). Especially, $\mathrm{Bi}_{2} \mathrm{O}_{3}$ as an important functional-doped material offers more potential applications in sensors, catalysts, pigments, photocatalysts, superconductors and next generation data storage materials (Newnham et al 1971; Arora et al 1996; Popa et al 2000; Mehring 2007).

Solid electrolytes are the most important components of solid-state electrochemical devices, which are becoming increasingly important for applications in energy conversion, chemical processing, sensing and combustion control. Bismuth oxide systems exhibit high oxide ionic conductivity and have been proposed as good electrolyte materials for applications such as solid oxide fuel cell and oxygen sensors. However, due to their instability under low oxygen partial pressure conditions, there has been difficulty in developing these materials as alternative electrolyte materials compared to state-of-the-art cubic-stabilized zirconia electrolyte. Bismuth oxide and doped bismuth oxide systems exhibit a complex array depending on the dopant concentration, temperature and atmosphere (Goff et al 1999; Lybye et al 2000; Shokr et al 2000).

\section{Materials and methods}

The powder samples were synthesized by the solid-state reaction method. According to the nominal composition $\left(\mathrm{Bi}_{2} \mathrm{O}_{3}\right)_{1-x}\left(\mathrm{Yb}_{2} \mathrm{O}_{3}\right)_{x}(x=0 \cdot 01-0 \cdot 08)$, appropriate amounts of starting materials, $\alpha-\mathrm{Bi}_{2} \mathrm{O}_{3}$ and $\mathrm{Yb}_{2} \mathrm{O}_{3}$, were thoroughly mixed and homogenized in an agate mortar. The mixtures 
were heat treated at 700,750 and $790{ }^{\circ} \mathrm{C}$. After each reaction, the products were cooled gradually until they reached room temperature. After each solid-state reaction, the product was examined to detect whether there was a change in the mass of the powder sample.

XRD data were recorded with a Bruker AXS D8 Advance model diffractometer (Bragg-Brentano geometry, graphite monochromator with $\mathrm{CuK}_{\alpha}$ radiation, $0.002^{\circ}$ pitch angle, $2 \theta=10-90^{\circ}$ ). Thermal measurements were made by using a simultaneous DTA/TG system (Perkin Elmer Diamond type). The samples of $\beta-\mathrm{Bi}_{2} \mathrm{O}_{3}$ doped with $\mathrm{Yb}_{2} \mathrm{O}_{3}$ were heated at a rate of $10{ }^{\circ} \mathrm{C} \mathrm{min}^{-1}$ from room temperature to $1000{ }^{\circ} \mathrm{C}$.

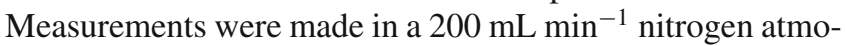
sphere using a platinum sample holder and an $\alpha-\mathrm{Al}_{2} \mathrm{O}_{3}$ inert reference substance.

The total electrical conductivity $\left(\sigma_{\mathrm{T}}\right)$ measurements were made on samples pelletized (diameter, $10 \mathrm{~mm}$, thickness, $\sim 1 \mathrm{~mm}$ ) using a four-probe d.c. method in the temperature range $100-750{ }^{\circ} \mathrm{C}$. To reduce contact resistance, fine platinum wires were attached directly to the surface of the samples. All data were made by a Keithley 2400 source meter and a Keithley 2700 electrometer, which were controlled by computer.

\section{Results and discussion}

The minimum temperature needed to obtain a crystal system that is stable in its simple phase under reaction circumstances is $750{ }^{\circ} \mathrm{C}$. Solid solutions were obtained in $\beta-\mathrm{Bi}_{2} \mathrm{O}_{3}$ crystallized in a tetragonal crystal system, in $\left(\mathrm{Bi}_{2} \mathrm{O}_{3}\right)_{1-x}\left(\mathrm{Yb}_{2} \mathrm{O}_{3}\right)_{x}$ in the range of $0.01 \leq x \leq 0.08$ mole fractions. The powderpatterns of 5 mole $\% \mathrm{Yb}_{2} \mathrm{O}_{3}$-doped solid solution are given in figure 1 as a sample.

All the designs of the samples indexed in the tetragonal crystal system show a similarity with the designs in figure 1 . The unit cell parameters of the $\beta$-phases are given in table 1 .

In figure 2, electrical conductivity plots of $\beta-\mathrm{Bi}_{2} \mathrm{O}_{3}$ doped with 8 mole $\% \mathrm{Yb}_{2} \mathrm{O}_{3}$ content are presented, and the $\sigma_{\mathrm{T}}$ plots for the other $\beta-\mathrm{Bi}_{2} \mathrm{O}_{3}$ phases are quite similar. These data were obtained during a repeated heating run at a constant heating rate in air. The electrical conductivity of $\beta-\mathrm{Bi}_{2} \mathrm{O}_{3}$ doped with 1-8 mole $\% \mathrm{Yb}_{2} \mathrm{O}_{3}$ increased with increasing temperature up to $\sim 659{ }^{\circ} \mathrm{C}$. Beyond this temperature conductivity increased sharply up to about $681^{\circ} \mathrm{C}$. The reason for the sharp increase in conductivity was the phase transition and an alteration in the crystal structure possibly causing a change in the conductivity mechanism. Structural disorder during transformation may also contribute to the improvement of ionic conductivity. The $\beta \rightarrow \delta$ phase transition for pure $\beta-\mathrm{Bi}_{2} \mathrm{O}_{3}$ at a temperature of about $660-670{ }^{\circ} \mathrm{C}$ has been reported using DTA thermal analysis and conductivity change graphs (Harwig and Gerards 1978, 1979) and experimental results showed that the $\delta-\mathrm{Bi}_{2} \mathrm{O}_{3}$ phase exhibited higher conductivity than the $\beta-\mathrm{Bi}_{2} \mathrm{O}_{3}$ phase. Actually, DTA/TG measurements also suggested that a polymorphic transition took place and the endothermic phase transition was observed on DTA curve at about the same temperature

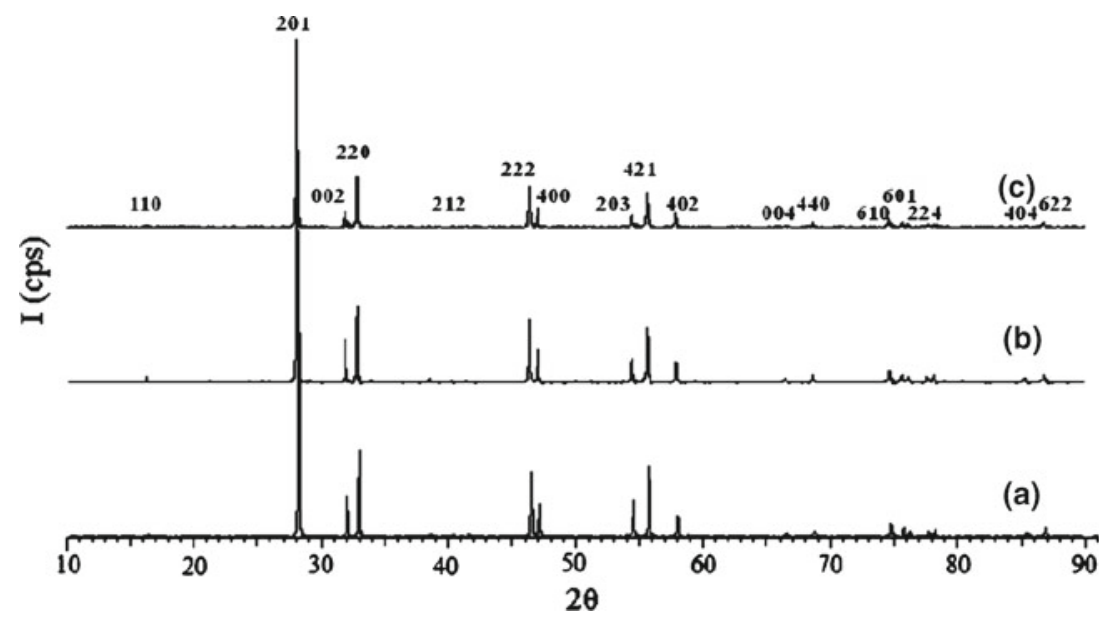

Figure 1. XRD patterns of $\beta-\mathrm{Bi}_{2} \mathrm{O}_{3}$ doped with 8 mole $\% \mathrm{Yb}_{2} \mathrm{O}_{3}$ : (a) at $700{ }^{\circ} \mathrm{C}$, (b) at $750{ }^{\circ} \mathrm{C}(48 \mathrm{~h})$ and (c) at $790{ }^{\circ} \mathrm{C}(120 \mathrm{~h})$.

Table 1. Relationship between amount of $\mathrm{Yb}_{2} \mathrm{O}_{3}$ doping and lattice parameter of $\beta-\mathrm{Bi}_{2} \mathrm{O}_{3}$.

\begin{tabular}{lccccccc}
\hline Mole $\% \mathrm{Yb}_{2} \mathrm{O}_{3}$ & 2 & 3 & 4 & 5 & 6 & 7 & 8 \\
\hline$a(\mathrm{pm})$ & $772 \cdot 6$ & $772 \cdot 1$ & $772 \cdot 2$ & $772 \cdot 0$ & $772 \cdot 6$ & $772 \cdot 5$ & $773 \cdot 1$ \\
$c(\mathrm{pm})$ & $563 \cdot 6$ & $563 \cdot 9$ & $563 \cdot 9$ & $563 \cdot 3$ & $563 \cdot 0$ & $563 \cdot 5$ & $562 \cdot 7$ \\
$V \times 10^{6}\left(\mathrm{pm}^{3}\right)$ & $336 \cdot 5$ & $336 \cdot 2$ & $336 \cdot 2$ & $335 \cdot 8$ & $336 \cdot 1$ & $336 \cdot 3$ & $336 \cdot 3$ \\
\hline
\end{tabular}




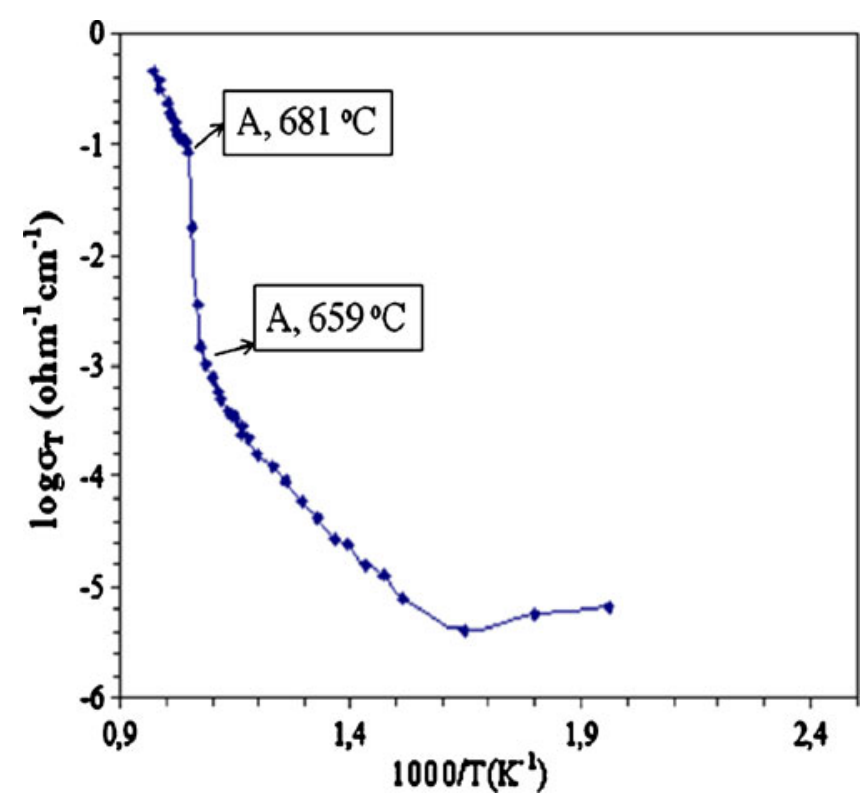

Figure 2. Electrical conductivity plot of $\beta-\mathrm{Bi}_{2} \mathrm{O}_{3}$ doped with 8 mole $\% \mathrm{Yb}_{2} \mathrm{O}_{3}$.

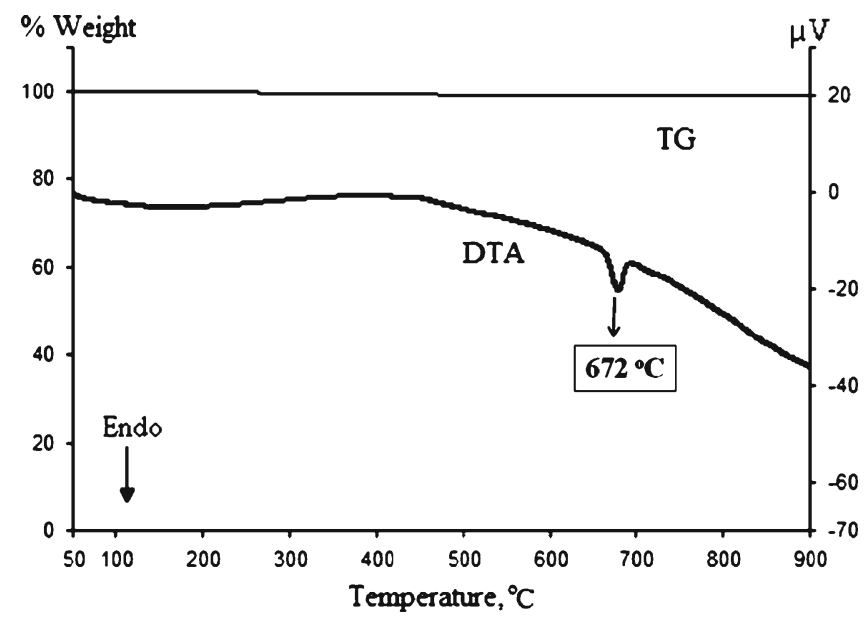

Figure 3. DTA/TG plot of $\beta-\mathrm{Bi}_{2} \mathrm{O}_{3}$ doped with 8 mole $\% \mathrm{Yb}_{2} \mathrm{O}_{3}$.

(figure 3). As can be seen in figure 3, the transition temperature is $\sim 672{ }^{\circ} \mathrm{C}$, which is determined by DTA; the transition temperature in the conductivity vs temperature graph is in the range of $659-681{ }^{\circ} \mathrm{C}$.

Producing a phase in the $\left(\mathrm{Bi}_{2} \mathrm{O}_{3}\right)_{1-x}\left(\mathrm{Yb}_{2} \mathrm{O}_{3}\right)_{x}$ system requires a long duration ( 48 and $120 \mathrm{~h}$ ) of heat application. In solid-state reactions that take place at high temperature, ytterbium (III) ions diffused gradually into the $\mathrm{Bi}_{2} \mathrm{O}_{3}$ lattice. If the doping process is successful, diffused ytterbium (III) cations prefer to change place with bismuth (III) cations in the lattice. This situation is thought to cause non-stoichiometry and transformation to a defect structure in the lattice as well as causing $\mathrm{O}^{2-}$ ion conductivity.

The experimental results showed that in our samples the oxygen lattice points of the $\beta-\mathrm{Bi}_{2} \mathrm{O}_{3}$ doped with $\mathrm{Yb}_{2} \mathrm{O}_{3}$ were not completely occupied with oxygen ions. If the oxygen sublattices were fully occupied by $\mathrm{O}^{2-}$ ions, the $\mathrm{Yb}_{2} \mathrm{O}_{3}$ doped $\beta-\mathrm{Bi}_{2} \mathrm{O}_{3}$ phases would not show such a high degree of electrical conductivity. Some of the oxygen lattice points located around the tetrahedral sites may have been vacant, forming an oxygen vacancy. These oxygen vacancies were filled randomly with neighbouring oxygen ions at an increasing rate with increasing temperature. Jumping oxygen ions left their former sites vacant, thus another vacancy was formed, since this process was random, the total oxygen flow was zero in any direction without an applied electric field.

The conductivity of $\beta-\mathrm{Bi}_{2} \mathrm{O}_{3}$ phases doped with $\mathrm{Yb}_{2} \mathrm{O}_{3}$ increased with increasing temperature. It was proposed that this was related to ionic mobility, which rises with increasing temperature. At elevated temperatures, the thermal vibrational energy of the ions increased causing a higher oxygen ion-jumping rate. Although oxygen vacancies were present in the crystal structure at low temperatures (below $200{ }^{\circ} \mathrm{C}$ ), the thermal energy of the anions was not high enough for them to jump out of their lowest energy positions. Thermal vibrations may also have assisted the jumping process for a short time by either shortening the jumping distance or by widening the jumping channels through the crystal.

\section{Conclusions}

As a result of this research, the $\beta$-phases of $\mathrm{Bi}_{2} \mathrm{O}_{3}$ substances which are unstable at room temperature were obtained by doping a $\mathrm{Yb}_{2} \mathrm{O}_{3}$ substance to $\alpha-\mathrm{Bi}_{2} \mathrm{O}_{3}$ substance with solidstate reactions. The effective factors in the synthesis of these polymorphs are high temperature application, reaction duration and the amount of $\mathrm{Yb}_{2} \mathrm{O}_{3}$ doped. It was observed that increasing the $\mathrm{Yb}_{2} \mathrm{O}_{3}$ amount influenced phase stability and those solid solutions that had a greater doping amount were more resistant to high temperature.

It can be concluded from the change of $\mathrm{Yb}^{3+}$ with crystal structured $\mathrm{Bi}^{3+}$ cations that non-stoichiometric phases were synthesized. Since the synthesis process was performed using a high-temperature application that lasted for a long period, we can say that ytterbium cations diffuse in the crystal structure very slowly. Tetragonal $\beta$-phase $\left(\mathrm{Bi}_{2} \mathrm{O}_{3}\right)_{1-x}\left(\mathrm{Yb}_{2} \mathrm{O}_{3}\right)_{x}(x=0 \cdot 01-0 \cdot 08)$ binary oxide compounds possessing oxygen ionic conductivity were synthesized. The non-stoichiometry of the $\beta-\mathrm{Bi}_{2} \mathrm{O}_{3}$ phase was thought to lead to interesting electrical properties.

The ionic conductivity in the $\beta-\mathrm{Bi}_{2} \mathrm{O}_{3}$ phases supports the view that there is an average occupation of oxide ions in oxygen lattice sites, which can move from site to site through the bismuth sublattice. The sample with the highest conductivity of $-0.338 \Omega^{-1} \mathrm{~cm}^{-1}$ at $750{ }^{\circ} \mathrm{C}$ was the $\beta$-phase of the $\left(\mathrm{Bi}_{2} \mathrm{O}_{3}\right)_{0.92}\left(\mathrm{Yb}_{2} \mathrm{O}_{3}\right)_{0.08}$ system.

\section{Acknowledgements}

This work was supported by Erciyes University (EUBAP). 


\section{References}

Arora N et al 1996 J. Catal. 1591

Cabot A et al 2004 Sensors Actuator B Chem. 9974

Chehab S et al 2003 Mater. Res. Bull. 38875

Crumpton T E, Francesconi M G and Greaves C 2003 J. Solid State Chem. 75197

Goff J P, Hayes W, Hulls S, Hutchings M T and Clausen K N 1999 Phys. Rev. B59 14202

Harwig H A 1978 Anorg. Allg. Chem. 444151

Harwig H A and Gerards A G 1978 J. Solid State Chem. 26265

Harwig H A and Gerards A G 1979 Thermochim. Acta 28121

Kalaycioglu N O and Çırçır E 2011 J. Chin. Chem. Soc. 581

Leontie L, Caraman M, Delibaș M and Rusu G I 2001 Mater. Res. Bull. 361629

Leontie L et al 2005 Thin Solid Films 473230
Lybye D, Poulsen F W and Mogensen M 2000 Solid State Ionics 12891

Mehring M 2007 Coord. Chem. Rev. 251974

Newnham R E, Wolfe R W and Dorrian J F 1971 Mater. Res. Bull. 61029

Ozpozan N and Çırçır E 2012 Synthesis and Reactivity in Inorganic, Metal-Organic and Nano-Metal Chemistry 42398 (DOI: 10.1080/15533174.2011.611565)

Popa M, Borodib G and Simon S 2000 J. Phys. Chem. Solids 61 1939

Sammes N M et al 1999 J. Eur. Ceram. Soc. 191801

Shokr E Kh, Wakkad M M, Abd El-Ghanny H A and Ali H M 2000 J. Phys. Chem. Solids 6175

Shuk P et al 1996 Solid State Ionics 89179

Takahashi T, Esaka T and Iwahara H 1977 J. Appl. Electrochem. 731 